\title{
The Disparity Between
}

Present Rates of Denudation

\section{and Orogeny}

By S. A. SCHUMM

SHORTER CONTRIBUTIONS TO GENERAL GEOLOGY

GEOLOGICAL SURVEY PROFESSIONAL PAPER 454-H

Modern rates of denudation and orogeny are compared, and the geologic implications of the disparity between them are considered

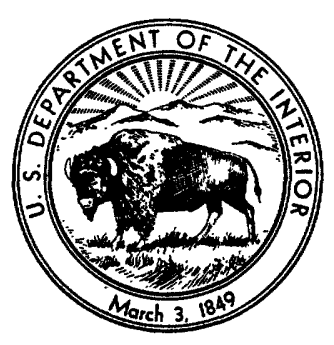


UNITED STATES DEPARTMENT OF THE INTERIOR

STEWART L. UDALL, Secretary

GEOLOGICAL SURVEY

Thomas B. Nolan, Director

For sale by the Superintendent of Documents, U.S. Government Printing Office Washington 25, D.C. 


\section{CONTENTS}

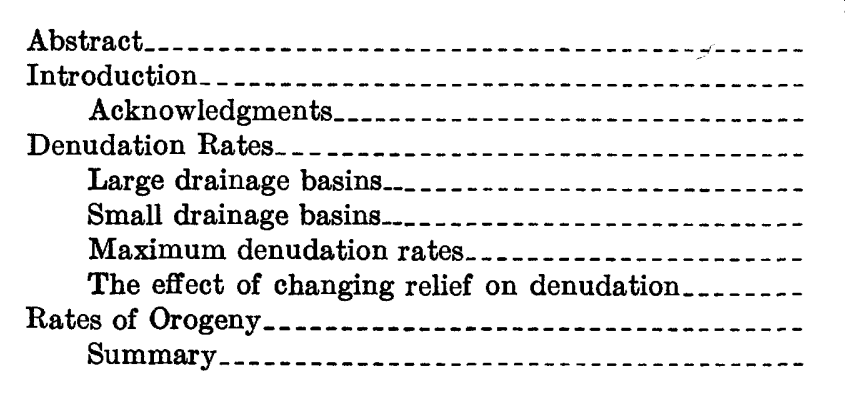

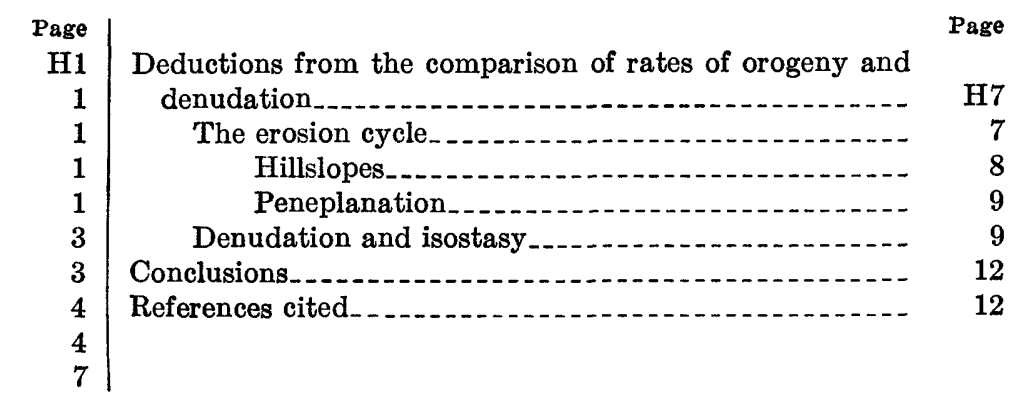

Page $\mathrm{H} 7$

7

9

\section{ILLUSTRATIONS}

Figure 1. Relation of sediment yield rates to relief-

2. Relation of denudation rates to relieflength ratio and drainage basin relief..... length ratio

Page H5

\section{TABLE}

TABLE 1. Denudation rates of drainage basins within the United States. 
. 


\title{
SHORTER CONTRIBUTIONS TO GENERAL GEOLOGY
}

\section{THE DISPARITY BETWEEN PRESENT RATES OF DENUDATION AND OROGENY}

\author{
By S. A. SснUмm
}

\begin{abstract}
Denudation rates are calculated for drainage basins, which average 1,500 square miles in area and which are underlain predominantly by sedimentary and metamorphic rocks. Average denudation rates range from 0.1 to 0.3 feet per 1,000 years, whereas, an average of maximum denudation rates is about 3 feet per 1,000 years. Denudation rates are an exponential function of drainage-basin relief, indicating that denudation rates increase rapidly with uplift.

Modern rates of orogeny are about 25 feet per 1,000 years, or about eight times greater than the average maximum denudation rate. As a result of this disparity between rates of orogeny and denudation, it is concluded that hillslope form is more a function of the difference between the rates of hillslope erosion and stream incision than of rates of uplift. This difference also makes it unlikely that a balance between rates of uplift and denudation will yield time-independent landforms.

Calculations of the time required for planation of 5,000 feet of relief suggest that ample time exists between orogenic periods for the development of peneplains.

Rapid orogeny accompanied and followed by relatively slower denudation should cause epicycles of recurrent uplift owing to isostatic adjustment to denudation. These phases of recurrent uplift after the cessation of tectonism may partly explain the existence of multiple erosion surfaces and terraces as well as the isostatic anomalies associated with old mountain ranges.
\end{abstract}

\section{INTRODUCTION}

The statement is often made that the rate of denudation for the entire United States approximates 1 foot in 10,000 years. It is difficult to grasp the significance of such a pronouncement, for when one considers the topographic and geologic variability of the continent, it is sure that no one rate of denudation is applicable to the whole. In addition, most geologic problems involve areas of less than continental extent, perhaps a mountain range or a section of a physiographic province. New data on sediment-yield rates from drainage basins of about 1,500 square miles in area or smaller, which are characterized by a variety of topographic, geologic, and climatic characteristics, permit calculation of denudation rates for relatively small areas.

Available data on recent rates of uplift afford an opportunity for consideration of the disparity between rates of mountain building and destruction. The ex- tension of present rates of denudation and orogeny into the past and into the future is valid only if the principle of uniformitarianism can be extended to rates as well as processes. At any given locality, denudation rates must have varied widely during the past; however, each time a mountain range existed in a given area, rates of denudation would have been high, and this in general should be true of the past as it is of the present. Gilluly $(1955$, p. 15) suggests that present rates of erosion are perhaps no greater than the average during the Cenozoic, and Menard (1961, p. 160) shows that denudation rates vary greatly, but "if mountainbuilding is random in time the rate of erosion of the whole world may be relatively constant when averaged for periods of $10^{7}-10^{8}$ years." It is necessary to assume that present rates of denudation and orogeny are representative of past rates if there is to be any consideration of geologic and geomorphic problems with regard to the rates presented here.

\section{ACKNOWLFDGMFNTS}

This paper was read by several people at one or another stage of its preparation. R. F. Hadley, G. C. Lusby, R. B. Raup, Jr., James Gilluly, and H. E. Malde of the U.S. Geological Survey and R. J. Chorley of Cambridge University all made suggestions which resulted in an improved manuscript. Dr. Gilluly's encouragement at a crucial stage in the preparation is deeply appreciated. The author also wishes to express his thanks to M. N. Christensen of the University of California at Berkeley for the time spent on a thorough reading and criticism of an early draft.

\section{DENUDATION RATES}

\section{LARGE DRAINAGE BASINS}

In contrast to sediment yield rates, which are the weight or volume of sediment eroded from a unit area, denudation rates are generally expressed as a uniform lowering of the land surface in feet per 1,000 years or years per foot of denudation. Obviously, no surface is lowered uniformly in this manner, but it is a convenient way to treat the data. 
The denudation rates given in recent geologic publications generally are those for large areas. For example, the rate for the Missouri River drainage basin is about 1 inch in 650 years or 1 foot in 7,800 years (Gilluly, Waters, and Woodford, 1951, p. 135). The same authors state that the rate of denudation for the entire United States is about 1 foot in 9,000 years, and that if this rate could be maintained without isostatic compensation all the landmass would be eroded to sea level in about 23 million years.

Russell (1909, p. 81-84) presents some data on 19th century attempts to calculate denudation rates. Those rates were uniformly high, for no consideration was given to the increase in volume involved in the conversion of rock to sediment.

Early in this century, Dole and Stabler (1909) presented calculations of rates of denudation for major river systems and geographic areas of the United States. Their rates of denudation for a few major rivers are as follows:

\begin{tabular}{|c|c|c|}
\hline River & $\begin{array}{l}\text { Drainage area } \\
\text { (square miles) }\end{array}$ & $\begin{array}{c}\text { Denudation } \\
\text { rate } \\
\text { (feet per } \\
1,000 \text { years) }\end{array}$ \\
\hline ----- & 1, 265,000 & 0.17 \\
\hline Missouri - & 528,000 & \\
\hline Colorado - & 230,000 & \\
\hline Ohio - & 214,000 & \\
\hline Potomac _- & 14,300 & \\
\hline Susquehanna - & 27,400 & \\
\hline
\end{tabular}

These rates are calculated from data obtained on the dissolved and suspended loads of streams; bedload is not included in the calculations. Dole and Stabler considered that each 165 pounds of sediment in the stream was equivalent to the erosion of 1 cubic foot of rock; in this way they adjusted for the difference in weight and volume between rock and sediment. Again these values, though of considerable interest, were derived from large areas throughout which the topography, geology, and climate varied greatly. Their average for the entire United States is 8,800 years per foot or, if it is assumed that the closed drainage basins of the Great Basin yield no sediment, 9,120 years per foot. These data are probably the source of the denudation rates of 9,000 to 10,000 years per foot that have been so widely quoted.

More recently the existing data have been reviewed, and two papers appeared almost simultaneously that afford new information on erosion from smaller areas (Langbein and Schumm, 1958; Corbel, 1959). Corbel has made a worldwide compilation of erosion rates, which for the most part include the total sediment load of streams. His data were summarized on the basis of climate (Corbel, 1959, p. 15), and indicate that the highest rates of erosion occur in glacial and periglacial regions (2 feet per 1,000 years). Erosion was high also in the high mountain chains having Mediterranean climate (1.5 feet per 1,000 years). In fact, one of the highest rates recorded in nonglacial regions was for the Durance River in southeastern France (1.7 feet per 1,000 years). Corbel's data reveal that denudation rates can be considerably in excess of those reported by Dole and Stabler (1909); this is true also of the Langbein-Schumm data for sediment yields within the United States. These data were averaged for certain ranges of effective precipitation, that is, precipitation adjusted to that yielding equivalent runoff in regions having mean annual temperature of $50^{\circ} \mathrm{F}$. The data show that sediment-yield rates are highest in semiarid regions (Langbein and Schumm, 1958, figs. 2 and 3 ).

Average values for two sets of sediment-yield data are presented in table 1 . The first set includes data from about 100 sediment-measuring stations maintained by the Geological Survey. A variety of climatic, topographic, and geologic types are represented, and the drainage areas average 1,500 square miles. The measurements of sediment load at these stations include the dissolved and suspended load but not the bedload. The second set of data are sediment yields from drainage basins averaging 30 square miles in area. As the sediment yield was obtained by measuring sediment accumulation in small reservoirs, these data represent an approach to total load, although small amounts of the suspended and dissolved material are probably lost through spillage of the reservoir.

TABLE 1.-Denudation rates of drainage basins within the United States

[From Langbein-Schumm data]

\begin{tabular}{|c|c|c|c|c|}
\hline $\begin{array}{l}\text { Effective precipitation } \\
\text { (inches) }\end{array}$ & $\begin{array}{c}2 \\
\text { Mean } \\
\text { sedi- } \\
\text { ment } \\
\text { yield } \\
\text { (tons } \\
\text { per } \\
\text { square } \\
\text { mile) }\end{array}$ & $\begin{array}{c}3 \\
\text { Mean } \\
\text { denuda- } \\
\text { tion } \\
\text { (feet } \\
\text { per } \\
1,000 \\
\text { years) }\end{array}$ & $\begin{array}{c}4 \\
\text { Mean } \\
\text { denuda- } \\
\text { tion } \\
\text { (years } \\
\text { per. } \\
\text { foot) }\end{array}$ & $\begin{array}{c}5 \\
\text { Time required } \\
\text { for planation } \\
\text { of } 5,000 \text { feet } \\
\text { of relief } 1 \\
\text { (millions of } \\
\text { years) }\end{array}$ \\
\hline \multicolumn{5}{|c|}{ Gaging-station data } \\
\hline $\begin{array}{l}10 \\
10-15 \\
15-20 \\
20-30 \\
30-40 \\
40-60\end{array}$ & $\begin{array}{l}670 \\
780 \\
550 \\
550 \\
400 \\
220\end{array}$ & $\begin{array}{r}0.29 \\
.34 \\
.24 \\
.24 \\
.17 \\
.10\end{array}$ & $\begin{array}{r}3,400 \\
2,900 \\
4,200 \\
4,200 \\
5,900 \\
10,000\end{array}$ & $\begin{array}{r}85 \\
75 \\
105 \\
105 \\
150 \\
250\end{array}$ \\
\hline \multicolumn{5}{|c|}{ Reservoir data } \\
\hline $\begin{array}{l}8-9 \\
10 \\
114-25 \\
25-30 \\
30-38 \\
38-40 \\
40-55 \\
55-100\end{array}$ & $\begin{array}{r}1,400 \\
1,180 \\
1,500 \\
1,130 \\
1,430 \\
790 \\
560 \\
470 \\
440\end{array}$ & $\begin{array}{l}0.61 \\
.51 \\
.65 \\
.49 \\
.62 \\
.34 \\
.24 \\
.21 \\
.19\end{array}$ & $\begin{array}{l}1,600 \\
2,000 \\
1,500 \\
2 ; 000 \\
1,600 \\
2,900 \\
4,200 \\
4,800 \\
5,300\end{array}$ & $\begin{array}{r}40 \\
50 \\
40 \\
50 \\
40 \\
75 \\
105 \\
120 \\
135\end{array}$ \\
\hline
\end{tabular}

1 Assuming a $5 \times$ isostatic adjustment, reduction of altitude by 1,000 feet requires 5, Assuming a $5 \times 1$ isostatic adjustment, reduction of altitude by 1,000 feet requir 
To convert the sediment-yield rates in tons per square mile to a denudation rate in years required to remove 1 foot of material, it is first necessary to convert the sediment tonnage to cubic feet of rock. An average density of sediment was assumed to be 2.64, and the sediment yield in pounds per square mile was divided by 165 to yield the volume of the surface of the earth removed per square mile per year. Thus, the erosion of 1 ton of sediment per square mile equals the removal of 12.1 cubic feet of rock which is equivalent to $4.34 \times 10^{-7}$ foot of denudation per year. The average denudation rates for the two sets of LangbeinSchumm data are listed in table 1 . The rates are higher than those presented by Dole and Stabler (1909) and are similar to some of the average values presented by Corbel (1959) but do not approach his maximum values, for the sediment yield rates presented in table 1 are average values based on effective precipitation, and the range of individual values comprising each mean is great.

\section{SMALL DRAINAGE BASINS}

Even higher denudation rates occur in drainage basins smaller than 30 square miles; for example, a small drainage basin eroded into the sediments of the White River Group of Oligocene age in Nebraska yields 32 acre-feet of sediment per square mile annually (Schumm and Hadley, 1961, fig. 1). Denudation is occurring in this small basin at a rate of 24 feet per 1,000 years. The Halls Debris Basin in the San Gabriel Mountains of California trapped 29.95 tons of sediment per acre of drainage basin per year, between 1935 and 1954 (Flaxman and High, 1955). This material is eroded from an area of 1.06 square miles and at a rate of 8.5 feet per 1,000 years. The maximum sediment-yield rate recorded by the Federal Interagency River Basin Committee (1953, p. 14) is 97,740 tons per square mile for a small drainage basin located in the Loess Hills area of Iowa. The drainage area of this basin is 0.13 square mile. With a sediment yield of this magnitude, denudation will progress at a rate of 42 feet per 1,000 years. This high rate, however, is due to gullying in loess rather than erosion of bedrock. Obviously, the above rates are extreme, but one objective of this report is to indicate that, in the light of recent studies of sediment-yield rates, our concepts of the time required for denudation of less than continental areas should be revised downward.

\section{MAXIMUM DENUDATION RATES}

Denudation in large areas requires more time, and in general the sediment yield per unit area decreases at about the -0.15 power of drainage-basin area (Brune,
1948, figs. 6 and 7; Langbein and Schumm, 1958, p. 1079). Sediment from the upper part of the larger basins may be deposited, eroded, and redeposited several times before reaching the basin mouth, although very high denudation rates may pertain to headwater areas. In the smaller basins, steeper slopes allow rapid and generally efficient transport of sediment through and out of the system. For example, on the basis of Brune's (1948) relation between drainage area and sediment yield, it can be calculated that the maximum denudation rate from the Loess Hills area should decrease from 24 to 10 feet per 1,000 years as the size of the drainage basin increases from 0.13 to 1500 square miles. In addition, the denudation rate of 8.5 feet per 1,000 years for the Halls Debris Basin, which has a drainage area of 1.06 square miles, would decrease to about 5 feet per 1,000 years in a 30 -square-mile drainage basin, and it would decrease to about 2.8 feet per 1,000 years in a 1,500 -square-mile basin. This rate approaches that of the Durance River mentioned by Corbel and other large drainage basins in mountainous areas.

Can this denudation rate of about 3 feet per 1,000 years be considered an average maximum rate for drainage basins on the order of 1,500 square miles in area? It is instructive to compare this rate with rates of erosion in some major mountain ranges. Wegman $(1957$, p. 6) refers to some earlier work to show that the northern Alps are being lowered at a rate of about 2 feet per 1,000 years. Khosla (1953, p. 111) reports on the suspended sediment yield from the Kosi River above Barakshetra, Bihar, India, which has a drainage basin of 23,000 square miles. Within this basin lie the highest mountain peaks in the world, Mount Everest and Mount Kanchenjunga. The annual suspended sediment yield from this basin is 4.1 acre-feet per square mile which, when converted to a denudation rate and adjusted for change in volume, equals a denudation rate of 3.2 feet per 1,000 years. These limited data indicate that 3 feet per 1,000 years approximates an average maximum rate of denudation.

The denudation rates as calculated here may be extremely high in comparison to those of the geologic past, for man's activities are known to have increased erosion rates many times in certain areas. Yet Gilluly (1949) estimates that 3 miles of denudation occurred in the Rocky Mountains during the Late Cretaceous. If the duration of the Late Cretaceous was 27 million years (Kulp, 1961), denudation occurred at a rate of 0.59 feet per 1,000 years which is almost twice the rate for the large drainage basins (table 1). Gilluly (1949, p. 570-571) also indicates that 5,000 feet of sediment were eroded from the Ventura Avenue anticline in 
about 1 million years. This is a denudation rate of 5 feet per 1,000 years, a rate higher than the maximums calculated above. Thus, a denudation rate of 3 feet per 1,000 years may not be excessive during the early stages of the erosion cycle when relief is high.

\section{THE EFFECT OF CHANGING RELIEF ON DENUDATION}

The denudation rates presented in table 1 are average values which may be used to calculate the time required for peneplanation. It is well known, however, that the rates of denudation change with uplift or during an erosion cycle. Other factors remaining constant, denudation rates will be dependent on the relief of a drainage basin. Data are available on the sediment yields from drainage basins of about 1 square mile in area that are underlain by sandstone and shale in semiarid regions of the western United States. When these data are plotted against the average slope or relative relief of the drainage basin (relief of basin divided by basin length) in figure 1, sediment-yield rates are found to be an exponential function of this relief-length ratio (Schumm and Hadley, 1961). In log form the equation for the regression line of figure 1 is

$$
\log S=27.35 R-1.1870 \text {, }
$$

where $S$ is sediment yield in acre-feet per square mile and $R$ is relief-length ratio. This relation is a straight line when plotted on semi-log paper. When plotted on arithmetic paper, the resulting curve shows clearly the rapid increase in sediment yield or denudation rates with the increase in relief-length ratio. This relation is shown on figure 2 (curve 2), where the sediment-yield rates have been converted to denudation rates for drainage basins 1,500 square miles in area and are plotted against relief-length ratio. Because basin length is constant, figure 2 can also show the increase in denudation rates as the relief of a drainage basin is increased to 30,000 feet. The equation for curve 2 in figure 2 is

$$
\log D=26.866 H-1.7238
$$

where $D$ is denudation in feet per 1,000 years and $H$ is relief-length ratio.

To return to the problem of maximum denudation rates for mountainous areas, it is now possible to adjust the data of Table 1 for an increase in relief. The data for the gaging stations on table 1 indicate that the maximum average rate occurs in a semiarid climate and is 0.34 feet per 1,000 years. As the slope or relief of the basins is increased, however, as it would with uplift, the sediment-yield rates will increase greatly. For example, when the average slope of a drainage basin or the ratio of relief to length increases from 0.005 to about 0.05 during orogeny then, according to the relation between relief-length ratio and sediment yield (fig. 1), such an increase in basin mean slope would increase sediment yield rates roughly tenfold. When this relationship is applied to the data of table 1 , the gaging-station data yield a maximum rate of 3.4 feet per 1,000 years. The maximum rate for the reservoir data is 6.7 feet per 1,000 years, but when this value for the small basins is extended to a 1,500-square-mile basin, it becomes 3.6 feet per 1,000 years. Therefore, as suggested previously, a value of about 3 feet per 1,000 years may approach the average maximum rate of denudation for mountainous areas.

When this average maximum rate of denudation for drainage basins having an average relief-length ratio of 0.05 is plotted on figure 2, the point falls far to the left of curve 2. A curve drawn through this point (curve 1, fig. 2) may represent the maximum denudation rates for a given relief-length ratio. Undoubtedly a family of curves would be required to show the relation between denudation rates and relief-length ratio for varying lithology and climate. As rock resistance and vegetative cover increase, the curve should shift to the right.

Figure 2 may be viewed in another manner. If the curves can be considered the locus of points occupied by one drainage basin during a cycle of erosion (high relief is analogous to the geomorphic stage of youth), then the decrease in denudation rates with time during the erosion cycle is illustrated.

In all the preceding discussion it should be remembered that the data on which figures 1 and 2 are based are representative of small drainage basins under a semiarid climate and underlain by sedimentary rocks. Therefore, only the general shape of the curves and the form of equation 1 may be considered as an approximation to large-scale denudation.

\section{RATES OF OROGENY}

Before one can discuss the implications of the denudation rates presented here, consideration should be given to rates of orogeny. To be comparable to modern rates of denudation, the rates of orogeny should be modern measured rates rather than rates based on a study of the geologic history of an area. For example, Zeuner $(1958$, p. 360) presents data showing that uplift occurs at rates of a fraction of a millimeter per year when the age of a formation exposed in the Alps or Himalayas is divided by its present altitude. The rates obtained are only minimum values for the actual rate of uplift, which probably occurred during a relatively short time. 
$\prod_{0}^{\infty}$

Sediment yield (acre-feet per square mile)

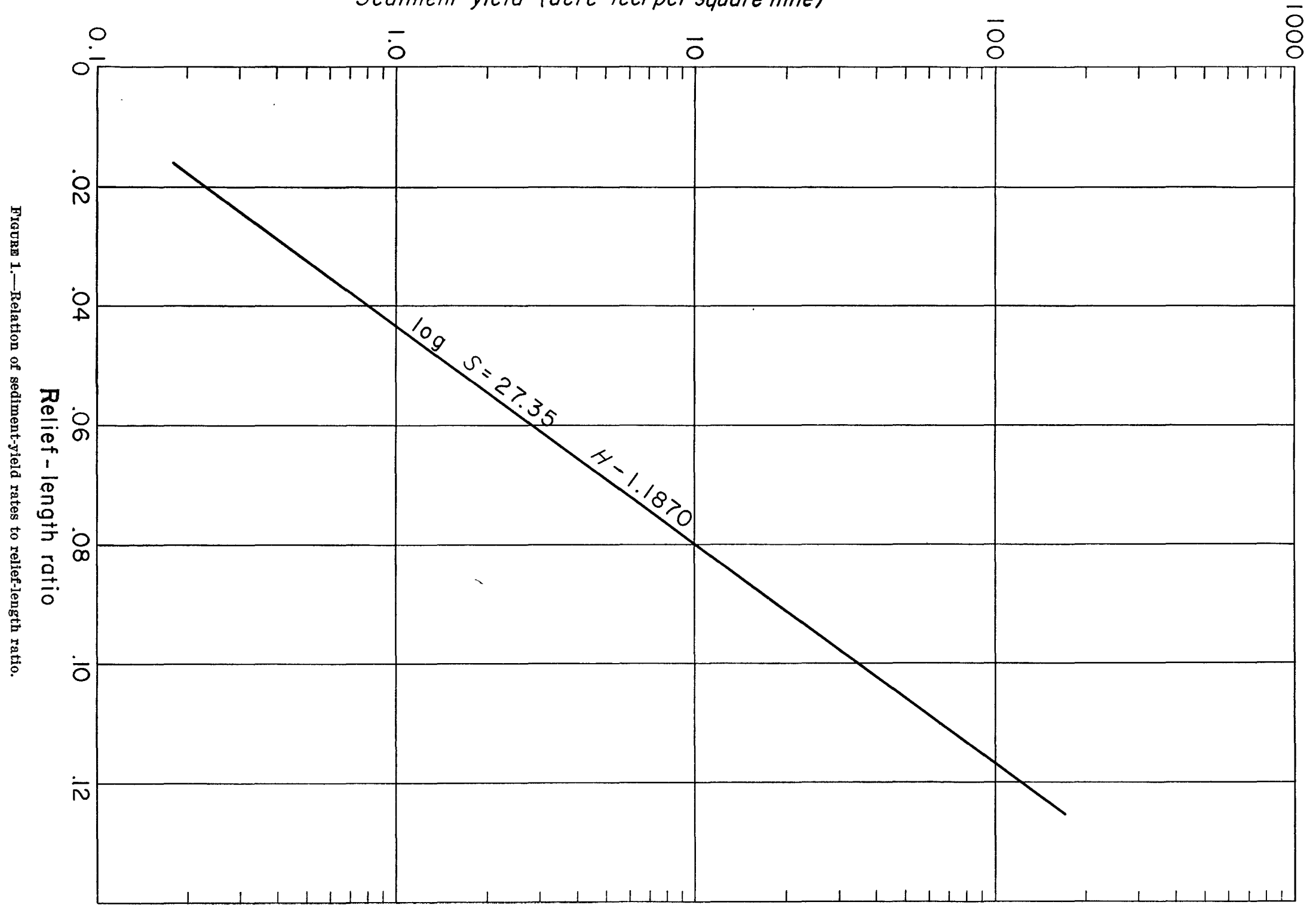

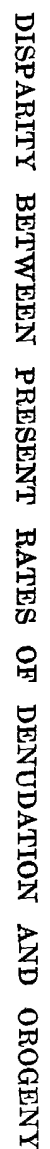




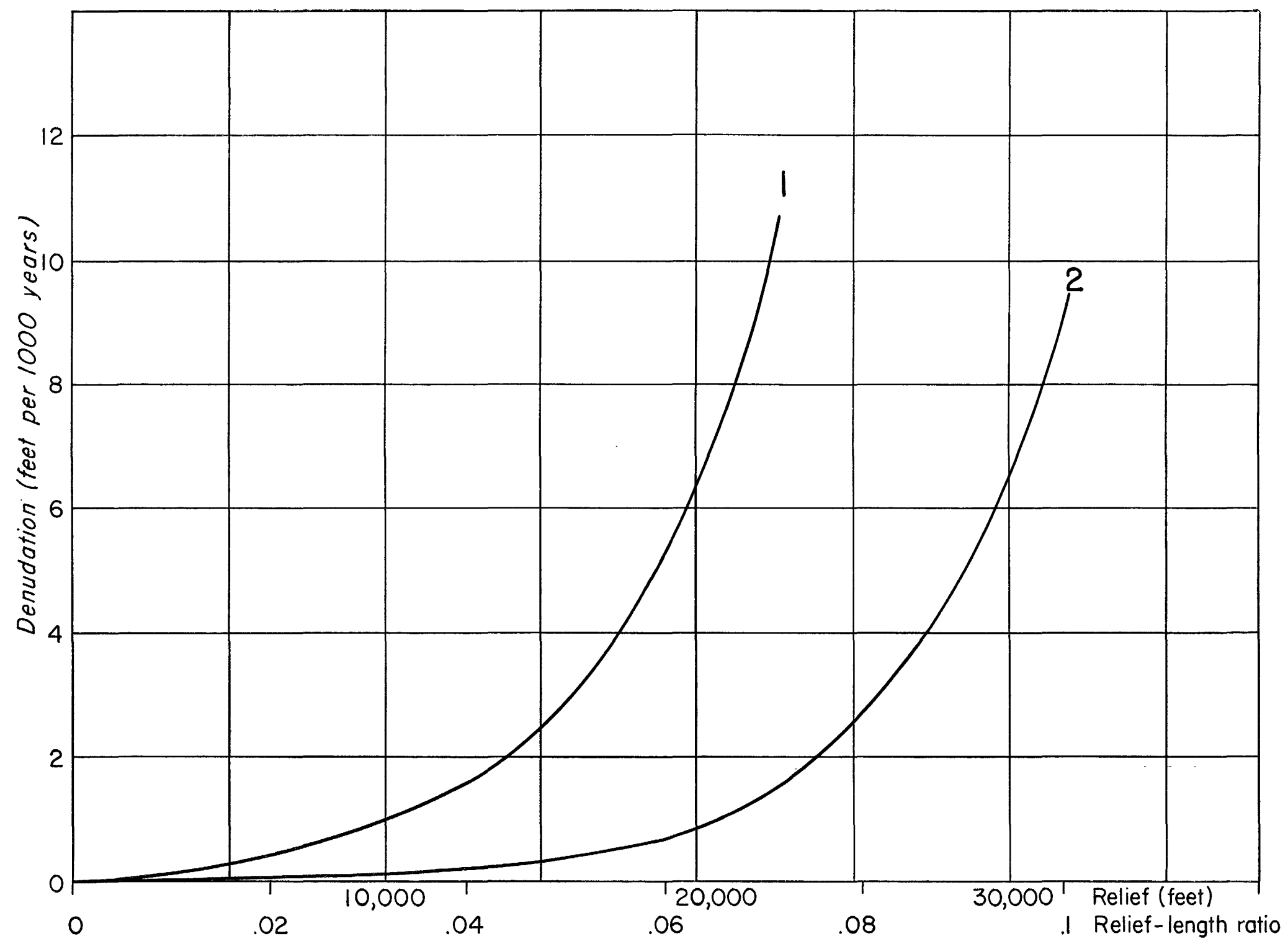

FIGURR 2.-Relation of denudation rates to relief-length ratio and drainage-basin relfef. Denudation rates are adjusted to drainage areas of 1,500 square miles. Curve 1 is based on the arerage maximum denudation rate of 3 feet per 1,000 years when relief-length ratio is 0.05. Curve 2 is based on relation shown in figure 1 . 
Rates of orogeny being measured at the present instant of geologic time are far in excess of the minimum values obtained by geologic studies. Gilluly (1949) lists some rates of uplift for areas in California in an effort to demonstrate that orogeny is an important aspect of the present. The rates listed are as follows:

Location

Uplift (feet per 1,000 years)

San Antonio Peak17

Buena Vista Hills

Cajon Station

Baldwin Hills

Alamitos Plain

20

29

The average of these values is 25 feet per 1,000 years. All these rates of uplift are greatly in excess of the highest rates of denudation presented in table 1 , but they are of the same order of magnitude as maximum rates of denudation for very small areas underlain by easily erodible materials, loess and shale.

A recent report on rates of orogeny (Stone, 1961) from results of repeated precise leveling in the Los Angeles area reveal that some stations on the flanks of the Santa Monica Mountains are rising at a rate of 13 feet per 1,000 years. This rate applies also to some stations on the south flank of the San Jose Hills. Stations on the south flank of the San Gabriel Mountains are rising at a rate of 20 feet per 1,000 years.

Gutenberg (1941) has compiled information on postglacial uplift in Fennoscandia and North America. Maximum uplift at the head of the Gulf of Bothnia is 110 centimeters per 100 years or 36 feet per 1,000 years. Geologic evidence indicates the total uplift during the past 7,000 years to be 100 meters or a rate of 48 feet per 1,000 years. Present rates of uplift in North America are 50 centimeters per 100 years to the north of Lake Superior, a rate of 16 feet per 1,000 years. Gutenberg (1941) estimates that present rates of uplift average about half the average for the past 4,000 years. Uplift of about 500 meters has occurred and an additional uplift of 200 meters is required to establish equilibrium. Because over two-thirds of the adjustment has been accomplished, the rates of uplift are slowing but still are high in comparison to rates of denudation.

In contrast to uplift occurring as a result of decrease of load, Lake Mead provides an example of rapid subsidence caused by the addition of 40 billion tons of water and 2 billion tons of sediment (Gould, 1960) to an area of 232 square miles ( 147 pounds per square inch). Subsidence is occurring at a rate of 40 feet per 1,000 years although total subsidence is expected to be only 10 inches (Longwell, 1960).

Average rates of uplift measured on the eastern European plain of Russia range from 6.5 to 13 feet per 1,000 years (Mescheryakov, 1958); maximum rates are
33 feet per 1,000 years. Data presented by Tsuboi (1933) show an average rate of uplift for leveling stations in Japan of 15 feet per 1,000 years and a range from 250 to 2.6 feet per 1,000 years. Lees (1955) reports rates of uplift in the Persian Gulf area at 33 and 10 feet per 1,000 years.

The above rapid rates of uplift were measured in tectonically active areas or those adjusting to increase or decrease of load. On the other hand, data obtained on epeirogenic uplift along seacoasts (Cailleux, 1952) show that uplift is occurring at an average rate of only 3.2 feet per 1,000 years. The range is from 12 to 0.3 feet per 1,000 years. It is to be expected that slow rates of uplift will be measured even in tectonic areas, for the beginnings and end of orogeny are probably slow.

Some data on present rates of orogeny indicate that these rates are very rapid. Although it is not certain that uplift will continue at these rates, it seems probable that the formation of mountain ranges occur at rates comparable to the rates measured in existing mountains. That is at a rate approaching 25 feet per 1,000 years.

\section{SUMMARY}

Calculations based on the best available recent data indicate that denudation will occur at the average maximum rate of 3 feet per 1,000 years in the early stage of the erosion cycle and that an average rate of denudation will be about 0.25 feet per 1,000 years when effective precipitation is less than 40 inches and drainage area is 1,500 square miles.

The relation of relief-length ratio to sediment yield shows that denudation rates will be an exponential function of drainage-basin slope or the relief of a drainage basin of constant size as it is raised by uplift or lowered by denudation. Modern rates of orogeny are about 25 feet per 1,000 years, or about 8 times greater than the average maximum rate of denudation. Existing data show a marked unbalance between the recent rates of orogeny and denudation.

\section{DEDUCTIONS FROM THE COMPARISON OF RATES OF OROGENY AND DENUDATION}

Based on the preceding conclusion that rates of orogeny are rapid in relation to maximum rates of denudation, it is possible to reconsider some classic geologic and geomorphic problems relative to hillslopes, peneplains, and the effects of isostastic adjustment and denudation on landforms.

\section{THE EROSION CYCLE}

Davis' assumption of rapid uplift of mountain ranges, which allows little erosional modification of the area before the cessation of uplift, is supported to 
some extent by the disparity between rates of uplift and denudation. Depending on rock type, the rapidly uplifted block may either be little modified by stream incision or significantly modified by it. Nonetheless, when uplift stops, channel incision should be occurring at a maximum rate. The uplifted area, therefore, would be in a youthful stage of geomorphic development or in the beginning of the Davisian cycle. However, if there is isostatic adjustment during the cycle of erosion, uplift will reoccur, perhaps intermittently, throughout much of the cycle. This will extend the duration of and complicate the cycle, but the basic principle of the evolution of landforms from a youthful topography is not changed.

\section{HILLSLOPES}

If channel incision is occurring at a rapid rate when uplift ceases, a hillslope profile will not reflect varying rates of diastrophism as suggested by Penck (1953), for long before the slope form could change from convex to concave in response to a waning of the endogenetic forces, uplift would have ceased.

In spite of the fact that most rates of orogeny exceed maximum denudation rates, it is possible to conceive of extremely slow, perhaps epeirogenic, uplift. When uplift is slow in an area of high relief, denudation would be at a maximum, and the landforms would change in relation to the dominant factor of rapid denudation rather than from the effects of slow uplift. If the uplift were long-continued, however, the decrease in the rate of denudation with reduction of relief might continue until it equalled the rate of slow uplift. It is difficult to visualize what effect this balance might have on landforms, but it has been suggested that when uplift and denudation are equal an equilibrium or timeindependent landform develops (Penck, 1953, Wegman, 1957, p. 5). If an area of low relief is slowly uplifted at rates equal to or less than the denudation rates, it would seem that little change in the landscape would occur and that again equilibrium landforms, whatever these might be, would be maintained.

This conclusion is, I believe, incorrect and results from the fallacy of assuming that because denudation rates are calculated as a uniform lowering of a land surface that denudation, in fact, occurs in this manner. Obviously it does not, for the forces of denudation are composed of two parts, hillslope erosion and stream channel erosion. Channel erosion may be rapid and in some cases approach the rate of uplift, but hillslope erosion is much less effective in lowering interfluve areas. A theoretically perfect balance between rates of uplift and denudation will, therefore, manifest itself by channel incision and extension of the drainage pat- tern. Mescheryakov (1959), for example, attributes recent channel erosion in the south Russian steppes to contemporary uplift.

Attempts to relate hillslope form to the interaction of rates of uplift and denudation (Penck, 1953) seem misguided in view of the importance of factors other than orogeny in determining hillslope form. Variations in hillslope form in areas of homogenous materials can best be explained as the result of available relief (Glock, 1932; Schumm, 1956a) or the erosion process (Schumm, 1956b).

The data presented here show that uplift in orogenic areas will be rapid. In fact, figure 2 (curve 2 ) shows that maximum denudation rates do not reach the average rate of uplift, 25 feet per 1,000 years, until relief is well above 20,000 feet. If so, differences in hillslope form should not be a result of the disparity between uplift and denudation, but probably are the result of the difference between the two components of denudation, rates of channel incision and hillslope erosion. For example, when rocks are very resistant, channel incision will be relatively much greater than hillslope erosion and a narrow canyon is formed. When the rock is less resistant, weathering and erosion on the upper slope form a convex profile. More easily eroded material will pass from an initially convex to a straight and then possibly to a concave profile in relatively rapid succession. This evolution has been noted in badlands (Schumm, 1956a, p. 635), where erosion in the channels and on the slopes proceeds at a rapid rate. Time-independent or equilibrium landforms probably cannot result from a theoretical balance between uplift and denudation. If time-independent forms did develop, it would be as a result of rapid channel incision in response to rapid uplift. For example, if uplift is rapid and of a large amount, initial channel incision will form convex hillslopes, but as channel deepening continues and if the rock is easily eroded, steep straight slopes will result which may be maintained at an angle typical of this material (Strahler, 1950). Again such slopes have been observed in badland areas where channel incision and slope erosion is rapid (Schumm, 1956b).

In conclusion, although slow uplift cannot be neglected entirely, rapid uplift probably is the rule in orogenic areas, as the existence of mountains attest. If rates of uplift in orogenic regions always exceed denudation rates, then hillslope form will not reflect the relation between uplift and denudation. Further, a theoretical balance between rates of uplift and denudation would be reflected in channel incision rather than by equilibrium landforms. 
PENEPLANATION

Some questions have been raised not only with regard to the cycle of erosion but also with regard to the peneplain itself. For example, Gilluly's (1949) conclusion that diastrophism has not been periodic but was almost continuous through time has been used as evidence against the uninterrupted evolution of landforms through a cycle of erosion as deduced by Davis. This objection has also been leveled at the concept of peneplanation (Thornbury, 1954, p. 189). However, Gilluly qualified the above statement to indicate that the location of diastrophic movements has continually changed. This shift in location is the crucial point in this connection, for when a period of stability occurs in a given tectonic area, a pediment or peneplain may form if the period of stability is long enough.

Davis (1925) estimated 20 to 200 million years was required for the planation of fault-block mountains in Utah. If, as some assume (de Sitter, 1956, p. 471), there are periods of about 200 million years of "relative quiescence" following shorter periods of diastrophism, then the cycle of erosion must run its course and peneplanation must occur within 200 million years. The upper estimate of Davis is close to the maximum allowable time, and the need for such long periods of stability introduces an element of the implausible.

Recent estimates of the time involved in peneplanation involve much shorter periods; without isostatic readjustment, the continental United States could be reduced to base level in about 10 million years (Gilluly, 1955, p. 15). This figure is only one-twentieth of the allowable time, but no correction for isostatic readjustment during erosion of this mass of rock has been made. This is an extremely important factor which may increase the time required for peneplanation by a factor of five or much more. For example, Holmes (1945, p. 190) considers that to reduce a land surface by 1,000 feet, erosion of 4,000 feet of material would be required; that is, there would be 3,000 feet of isostatic adjustment to erosion. Gilluly $(1955$, p. 14) in his calculation of the time required for the planation of mountain areas, areas more than 0.2 kilometers in elevation, allows for the erosion of 5.5 times the volume of existing mountain areas owing to isostatic uplift. Considering this isostatic factor, Gilluly (1955) concludes that 33 million years are necessary for the planation.

To use the denudation rates presented in table 1 and figure 2 to calculate time required for peneplanation, it is necessary to consider the 1,500 square mile areas as components of a larger area. It is possible to visualize a series of such basins alined and forming a mountain range. Assuming our model mountain range is so composed and has 15,000 feet of relief then it should be possible to calculate the time required for peneplanation using the changing rates of denudation shown in figure 2. However, it is difficult to know what amount of denudation is required for peneplanation. It appears that if a mountain block were uplifted 15,000 feet, denudation may need only remove about 5,000 feet of rock, for the adjacent lowlands are being built up by deposition of sediment as the mountains are eroded. This is a complication not shown in figure 2.

Let us assume that 5,000 feet of rock must be eroded for peneplanation. If rates of denundation for the 1,500-square-mile drainage basins are average, all except the basins within the 40-60 inch range of effective precipitation fall within the 200-million-year time limit for peneplanation (table 1 , column 5). If less than 5,000 feet of denudation were required for peneplanation, then all would fall within the time limit. The smaller drainage basins ( 30 square miles) require much less time for planation as expected (table 1). From figure 2 (curve 1) it is possible to obtain denudation rates during the lowering of the mountain range 5,000 feet. At 15,000 feet on the maximum curve, denudation is 2.6 feet per 1,000 years; at 10,000 feet denudation is 1.1 feet per 1,000 years. If the denudation rate at 12,500 feet (1.6 feet per 1,000 years) is the average of these rates, 3 million years are required for the reduction of 5,000 feet of relief. If isostatic compensation requires a 5 -fold adjustment, then peneplanation will occur in 15 million years.

On the curve obtained from sediment yields of small drainage basins (fig. 2, curve 2), the average denudation rate between 15,000 and 10,000 feet is 0.23 feet per 1,000 years. At this rate peneplanation would require about 110 million years. These periods of time seem short enough to make peneplanation a distinct possibility in the geologic past.

Much has been ignored in the above analysis, for example, the effects of uplift on the climate of the area and vegetative changes'during geologic time. Nevertheless, if denudation occurred at the maximum rate, (3 feet per 1,000 years), an area with 5,000 feet of relief would be reduced to base level in 10 million years.

\section{DENUDATION AND ISOSTASY}

Isostatic adjustment to erosion will occur continuously with denudation only if the earth's crust behaves as a fluid. The crust has considerable strength locally (Gunn, 1949, p. 267) ; before isostatic adjustment can occur, this strength should be exceeded by the removal of rock by denudation. Indeed, even when the strength is exceeded there may be a lag before isostatic adjustment occurs as that which allowed submergence of glaciated lands following the melting of the Pleistocene 
ice sheets (Charlesworth, 1957, p. 1361). In addition, isostatic adjustment to the retreat of the Pleistocene ice sheets was episodic (Lougee, 1953). This adjustment may be explained most simply by assuming that isostatic adjustment accompanied periods of rapid melting of the ice and that no uplift occurred during pauses in deglaciation. However, one may object to this simple explanation on the grounds that pulses of rapid isostatic adjustment followed rapid melting with a lag of about 2,000 years (Charlesworth, 1957, p. 1345).

Many field studies indicate that discontinuous episodes of uplift occurred in most mountain ranges. For example, Wahlstrom (1947, p. 568) states that uplift of the Front Range in Colorado "to its present elevation was not the result of a single upheaval. The presence of more or less poorly developed terraces in the canyons $* * *$ and well-developed terraces in the valleys east of the mountains suggests intermittent uplifts."

In general, a discussion of these multiple terraces and stepped erosion surfaces, when it is assumed that they have been formed by uplift alone, raises the subject of the role of isostatic adjustment to denudation as a factor in their formation. Whether isostatic adjustment to denudation will occur in a given area depends on the local strength of the earth's crust. Any one of three conditions for adjustment may prevail in a given area: mechanical equilibrium whereby a rigid crust is capable of supporting uncompensated loads; isobaric equilibrium whereby there is a regional compensation for loading or unloading; and isostatic equilibrium whereby a local compensation to loading or unloading occurs along fractures in the crust (Hsu, 1958). Compensation for deglaciation is isobaric, whereas compensation for denudation will generally be isostatic.

The episodic nature of isostatic adjustment to deglaciation and the disparity between rates of uplift and denudation in orogenic areas suggest that isostatic adjustment to denudation will also be episodic. When initial diastrophism occurs, uplift will be relatively rapid until an equilibrium is approached. Orogeny will then cease, and denudation will proceed at a slower rate until the strength of the crust is exceeded, when rapid isostatic adjustment should occur. This relation is shown diagrammatically in figure 3. The orogeny raises the area 15,000 feet; during and following the orogeny, denudation rates increase to a maximum, to be followed by a decline as relief is lowered. This orderly sequence of events is interrupted by a short period of isostatic adjustment, during and following which denudation rates again increase to a maximum. If the result solely of isostasy, the succeeding uplifts will not reach the altitude of the initial uplift due to mountain-building processes. If such a relation between denudation and isostasy exists, the topographic form of many mountain ranges will be due to episodes of isostatic uplift as well as to the postorogenic uplift discussed by Pannekoek (1961). Depending on the strength of the crust in a given area, the recurrent isostatic adjustment may be long delayed and large, or more frequent and of smaller magnitude.

Renewed tectonism can interrupt these epicycles of denudation and uplift but, if tectonism ceased after initial uplift, the sequence of erosion and isostatic adjustment may be considered analogous to a positive feedback system. Initial uplift increases denudation rates which in turn increase the tendency for further uplift; when this removal of material per unit area is such that it exceeds the strength of the crust, isostatic adjustment occurs and the cycle begins again. These epicycles within the cycle of erosion occur because the components of the system, denudation and isostatic adjustment, operate at greatly different rates. These epicycles, if real, may partly explain the occurrence of multiple terraces, multiple or warped erosion surfaces, and piedmontreppen. For example, King (1955) and Pugh (1955) have attributed the multiple scarps and erosion surfaces formed in western and southern Africa to periods of isostatic adjustment caused by the retreat of major scarps over long distances from the sea coast.

With the preceding hypothesis in mind, it is instructive to compare the condition of isostatic adjustment in young and old mountain ranges. Most of the younger mountain ranges (Rockies, Alps, Andes, Himalayas) have a deficiency of mass at depth, which causes a Bouguer anomaly of about -300 milligals (mgal). This deficiency compensates for the mass of the mountains above sea level, and the young mountains are in isostatic balance. The old, eroded mountain ranges (Appalachians), however, have a smaller deficiency of mass, and although the Bouguer anomalies may be only 0 to $100 \mathrm{mgal}$, the mass deficiency is larger in many cases than is required for isostatic compensation. "As a result, isostatic anomalies of approximately $-50 \mathrm{mgal}$ may be obtained, indicating that erosion and reduction in elevation in these areas has proceeded faster than the readjustment of the compensating mass at depth" (Jacobs, Russell and Wilson, 1959, p. 100).

It would be possible to conclude from this quotation that denudation works faster than uplift, but the data just reviewed disprove this, even if (as figure 3 shows), during long periods of geologic time, denudation does continue while uplift is dormant. The isostatic anomalies in old, eroded mountain ranges, therefore, seem 


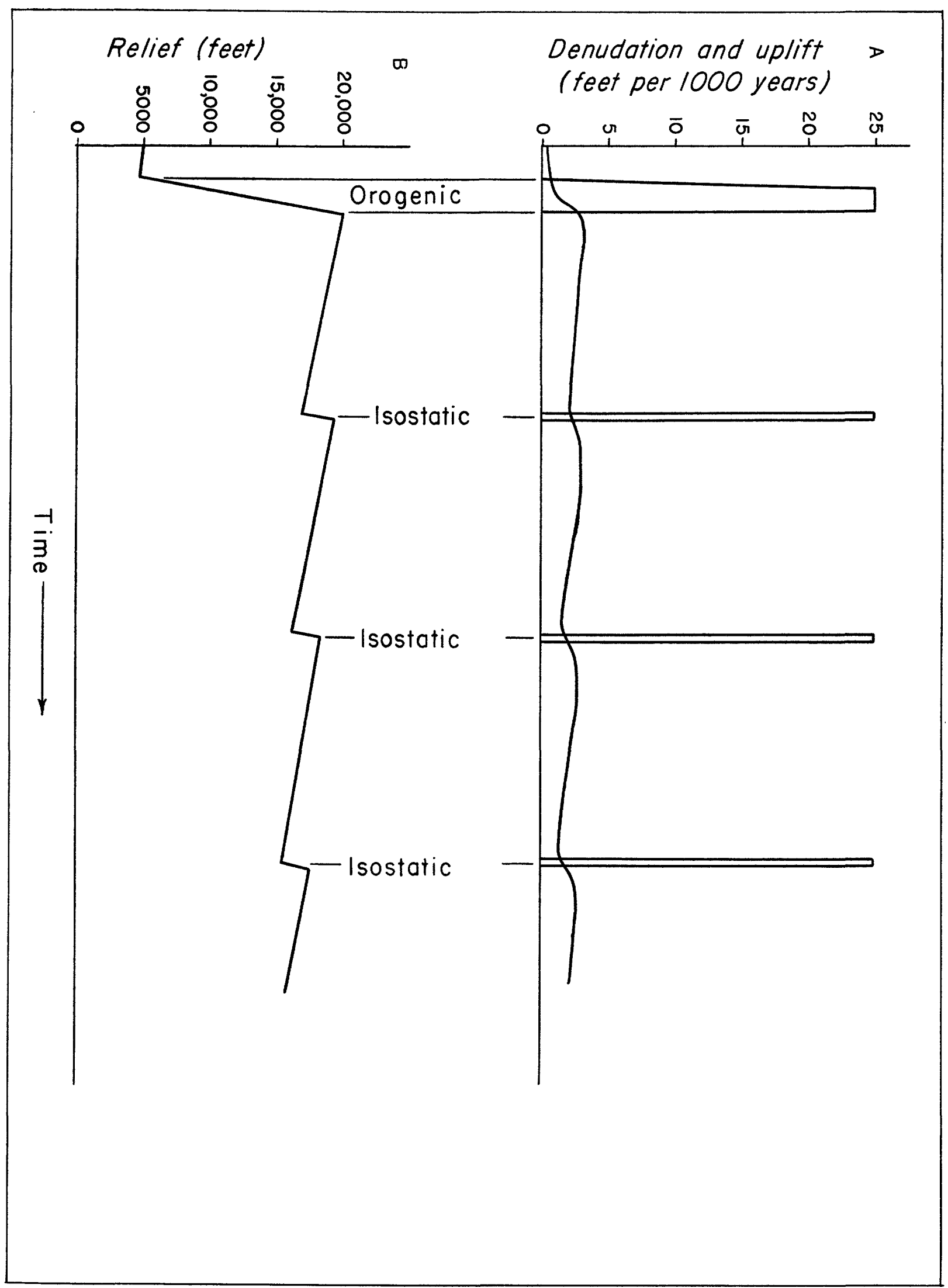

Figure 3.-A, Hypothetical relation of rates of uplift and denudation (solid line) to time. $B$, Hypothetical relation of drainagebasin relief to time as a function of uplift and denudation shown in $A$. 
to indicate that erosion, although considerable, is not enough to trigger another isostatic adjustment. The young mountain ranges, however, may not be significantly affected by denudation since the last isostatic adjustment, or these adjustments may occur more frequently in the younger ranges and prevent any major isostatic anomaly. Rapid denudation in the younger ranges of high relief make it likely that frequent adjustments keep the young ranges almost in isostatic balance.

Evidence of these epicycles should appear in the stratigraphic record. For example, in sediments derived from an area subjected to cyclic isostatic uplift, gravels might recur through a great thickness of sediment. An example of this as cited by Gilluly (1945) is the Sespe Formation of Eocene and Oligocene age which represents a depositional period of 12 to 15 million years. The recurrent uplift proposed by Gilluly to explain the persistence of coarse sediments in the Sespe Formation may be partly the result of isostatic adjustment to denudation as discussed above.

\section{CONCLUSIONS}

Tentative conclusions based on present rates of denudation and uplift are presented as follows :

1. Rates of denudation for areas of about 1,500 square miles average 0.25 feet per 1,000 years and reach a maximum of 3 feet per 1,000 years. These rates are relatively rapid and are representative of areas for the most part underlain by sedimentary rocks in a semiarid climate. Denudation rates in humid regions are about four times slower.

2. Present rates of orogeny exceed rates of denudation significantly. An average maximum rate of orogeny is about 25 feet per 1,000 years.

3 . The rapid rates of orogeny in contrast to denudation and valley cutting make it unlikely that hillslope form can be used to decipher the earth's recent diastrophic history. Rather the form of a hillslope profile in an area of high relief probably reflects the difference in rates of channel incision and hillslope erosion.

4. Because denudation has two components, channel and hillslope erosion, which operate at much different rates, a balance between rates of denudation and uplift will not yield time-independent or equilibrium landforms.

5. Relatively rapid rates of denudation make peneplanation a very likely event under conditions which were probably common in the geologic past. Planation of 5,000 feet of relief may require perhaps 15 to 110 million years.
6. An erosion cycle will be interrupted by periods of rapid isostatic adjustment separated by longer stable periods of denudation.

7. The episodic recurrence of isostatic adjustment may partly explain the existence of multiple or warped erosion surfaces, the recurrence of coarse sediments through a thick sedimentary deposit, and isostatic anomalies in old mountain ranges.

\section{REFERENCES CITED}

Brune, G., 1948, Rates of sediment production in midwestern United States: Soil Conservation Service Tech. Pub. 65, $40 \mathrm{p}$.

Cailleux, A., 1952, Récentes variations du niveau des mers et des terres: Geol. Soc. France, Bull. 6, v. 2, p. 135-144.

Charlesworth, J. K., 1957, The Quaternary era : London, Edward Arnold, 2 v., 1700 p.

Corbel, J., 1959, Vitesse de l'Érosion : Zeitschr. Geomorph., v. 3, p. 1-28.

Davis, W. M., 1925, The basin range problem: [U.S.] Natl. Acad. Sci. Proc., v. 11, p. 387-392.

Dole, R. B., and Stabler, H., 1909, Denudation: U. S. Geol. Survey Water-Supply Paper 234, p. 78-93.

Federal Inter-Agency River Basin Comm., 1953, Summary of reservoir sedimentation surveys for the United States through 1950: Subcomm. on Sedimentation, Sedimentation Bull. 5, 31 p.

Flaxman, E. M., and High, R. D., 1955, Sedimentation in drainage basins of the Pacific Coast States: Soil Conservation Service, Portland [mimeographed].

Gilluly, James, 1949, Distribution of mountain building in geologic time: Geol. Soc. America Bull., v. 60, p. 561-590.

1955, Geologic contrasts between continents and ocean basins: Geol. Soc. America Special Paper 62, p. 7-18.

Gilluly, J., Waters, A. C., and Woodford, A. O., 1951, Principles of geology : San Francisco, W. H. Freeman \& Co., 631 p.

Gould, H. R., 1961, Amount of sediment, in Smith, W. O., Vetter, C. P., Cummings, G. B., and others, Comprehensive survey of sedimentation in Lake Mead, 1948-49; U.S. Geol. Survey Prof. Paper 295, p. 195-200.

Glock, W. S., 1932, Available relief as a factor of control in the profile of a landform: Jour. Geology, v. 40, p. 74-83.

Gunn, R., 1949, Isostasy-extended: Jour. Geol., v. 57, p. 263279.

Gutenberg, Beno, 1941, Changes in sea level, postglacial uplift, and mobility of the earth's interior: Geol. Soc. America Bull., v. 52, p. 721-772.

Holmes, Arthur, 1945, Principles of physical geology : New York, Ronald Press, 532 p.

Hsu, K. J., 1958, Isostasy and a theory for the origin of geosynclines : Am. Jour. Sci., v. 256, p. 305-327.

Jacobs, J. A., Russell, R. D. and Wilson, J. T., 1959, Physics and geology : New York, McGraw-Hill Inc., 424 p.

Khosla, A. N., 1953, Silting of reservoirs: Central Board of Irrigation and Power [India] Pub. 51, 203 p.

King, L. O., 1956, Pediplanation and isostasy : An example from South Africa: Geol. Soc. London Quart. Jour., v. 111, p. 353-359.

Kulp, J. L., 1961, Geologic time scale: Science, v. 133, p. 11051114. 
Langbein, W. B., and Schumm, S. A., 1958, Yield of sediment in relation to mean annual precipitation: Am. Geophys. Union Trans., v. 39, p. 1076-1084.

Lees, G. M., 1955, Recent earth movements in the Middle East: Geol. Rundschau, v. 43, p. 221-226.

Longwell, O. R., 1960, Interpretation of the leveling data: U.S. Geol. Survey Prof. Paper 295, p. 33-38.

Lougee, R. J., 1953, A chronology of postglacial time in eastern North America : Scientific Monthly, v. 76, p. 259-276.

Menard, H. W., 1961, Some rates of regional erosion: Jour. Geol., v. 69, p. 154-161.

Meshcheryakov, Y. A., 1959, Contemporary movements in the earth's crust: Internat. Geol. Rev., v. 1, p. 40-51 (Translated by A. Navon from Sovremennyye dvizheniya zemnoy kory: Priroda, 1958, no. 9, p. 15-24).

Pannekoek, A. J., 1961, Post-orgenic history of mountain ranges : Geol. Rundschau, v. 50, p. 259-273.

Penck, W., 1953, Morphological analysis of landforms : (Translated) London, Macmillan, $429 \mathrm{p}$.

Pugh, J. C., 1955, Isostatic readjustment in the theory of pediplanation: Geol. Soc. London Quart. Jour., v. 111, p. 361-369.

Russell, I. C., 1909, Rivers of North America: New York, G. P. Putnam's Sons, 327 p.

Schumm, S. A., 1956a, Evolution of drainage systems and slopes in badlands at Perth Amboy, New Jersey: Geol. Soc. America Bull., v. 67, p. 597-646.
$1956 \mathrm{~b}$, The role of creep and rainwash on the retreat of badland slopes: Am. Jour. Sci., v. 254, p. 693-706.

Schumm, S. A., and Hadley, R. F., 1961, Progress in the application of landform analysis in studies of semiarid erosion : U.S. Geol. Survey Gircular 437, 14 p.

Sitter, L. U. de, 1956, Structural geology : New York, McGrawHill, Inc., 552 p.

Stone, Robert, 1961, Geologic and engineering significance of changes in elevation revealed by precise leveling, Los Angeles area, California [abs.]: Geol. Soc. America Spec. paper 68, p. $57-58$.

Strahler, A. N., 1950, Equilibrium theory of erosional slopes approached by frequency distribution analysis: Am. Jour. Sci., v. 248, p. 673-696, 800-814.

Thornbury, W. D., 1954, Principles of geomorphology: New York, John Wiley \& Sons, $618 \mathrm{p}$.

Tsuboi, O., 1933, Investigation on the deformation of the Earth's crust found by precise geodetic means: Japanese Jour. Astronomy and Geophysics : v. 10, p. 93-248.

Wahlstrom, E. E., 1947, Cenozoic physiographic history of the Front Range, Colorado: Geol. Soc. Am. Bull., v. 58, p. 551-572.

Wegman, E., 1957, Tectonique vivante, dénudation et phénomènes connexes : Rev. Géog. Physique et Géol. Dynamique, pt. 2, v. 1, p. 3-15.

Zeuner, F. E., 1958, Dating the past: 4th ed., London, Methuen \& Co., $516 \mathrm{p}$. 